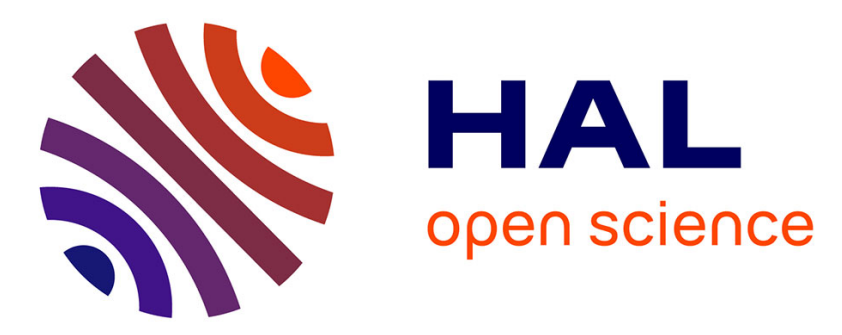

\title{
Cyclones influence native plant diversity on 22 remote high islands of French Polynesia and Pitcairn (eastern Polynesia)
}

\author{
Sébastien Larrue
}

\section{- To cite this version:}

Sébastien Larrue. Cyclones influence native plant diversity on 22 remote high islands of French Polynesia and Pitcairn (eastern Polynesia). Physical Geography, 2014, 35 (6), pp.497 - 513. 10.1080/02723646.2014.946808 . hal-01648247

\section{HAL Id: hal-01648247 \\ https://hal.science/hal-01648247}

Submitted on 25 Nov 2017

HAL is a multi-disciplinary open access archive for the deposit and dissemination of scientific research documents, whether they are published or not. The documents may come from teaching and research institutions in France or abroad, or from public or private research centers.
L'archive ouverte pluridisciplinaire HAL, est destinée au dépôt et à la diffusion de documents scientifiques de niveau recherche, publiés ou non, émanant des établissements d'enseignement et de recherche français ou étrangers, des laboratoires publics ou privés. 


\section{PROOF COVER SHEET}

Author(s): Sébastien Larrue

Article title: Cyclones influence native plant diversity on 22 remote high islands of French Polynesia and Pitcairn (eastern Polynesia)

Article no: TPHY 946808

Enclosures: 1) Query sheet

2) Article proofs

Dear Author,

1. Please check these proofs carefully. It is the responsibility of the corresponding author to check these and approve or amend them. A second proof is not normally provided. Taylor \& Francis cannot be held responsible for uncorrected errors, even if introduced during the production process. Once your corrections have been added to the article, it will be considered ready for publication.

Please limit changes at this stage to the correction of errors. You should not make trivial changes, improve prose style, add new material, or delete existing material at this stage. You may be charged if your corrections are excessive (we would not expect corrections to exceed 30 changes).

For detailed guidance on how to check your proofs, please paste this address into a new browser window: http://journalauthors.tandf.co.uk/production/checkingproofs.asp

Your PDF proof file has been enabled so that you can comment on the proof directly using Adobe Acrobat. If you wish to do this, please save the file to your hard disk first. For further information on marking corrections using Acrobat, please paste this address into a new browser window: http:// journalauthors.tandf.co.uk/production/acrobat.asp

2. Please review the table of contributors below and confirm that the first and last names are structured correctly and that the authors are listed in the correct order of contribution. This check is to ensure that your name will appear correctly online and when the article is indexed

\begin{tabular}{|c|c|c|c|c|}
\hline Sequence & Prefix & Given name(s) & Surname & Suffix \\
\hline 1 & & Sébastien & Larrue & \\
& & & & \\
\hline
\end{tabular}


Queries are marked in the margins of the proofs, and you can also click the hyperlinks below.

\section{AUTHOR QUERIES}

\section{General points:}

1. Permissions: You have warranted that you have secured the necessary written permission from the appropriate copyright owner for the reproduction of any text, illustration, or other material in your article. Please see http://journalauthors.tandf.co.uk/permissions/usingThirdPartyMaterial.asp.

2. Third-party content: If there is third-party content in your article, please check that the rightsholder details for re-use are shown correctly.

3. Affiliation: The corresponding author is responsible for ensuring that address and email details are correct for all the co-authors. Affiliations given in the article should be the affiliation at the time the research was conducted. Please see http://journalauthors.tandf.co.uk/preparation/writing.asp.

4. Funding: Was your research for this article funded by a funding agency? If so, please insert 'This work was supported by <insert the name of the funding agency in full >', followed by the grant number in square brackets '[grant number $\mathrm{xxxx}$ ]'.

5. Supplemental data and underlying research materials: Do you wish to include the location of the underlying research materials (e.g. data, samples or models) for your article? If so, please insert this sentence before the reference section: 'The underlying research materials for this article can be accessed at $<$ full link $>$ / description of location [author to complete]'. If your article includes supplemental data, the link will also be provided in this paragraph. See $<\mathrm{http}$ :/ journalauthors.tandf.co.uk/preparation/multimedia.asp $>$ for further explanation of supplemental data and underlying research materials.

6. The CrossRef database (www.crossref.org/) has been used to validate the references. Mismatches will have resulted in a query.

\begin{tabular}{|c|c|}
\hline $\mathrm{AQ1}$ & $\begin{array}{l}\text { Please check and confirm that the equation has been formatted correctly throughout } \\
\text { the article. }\end{array}$ \\
\hline AQ2 & Please provide missing page numbers for the "Dahl 1980 " references list entry. \\
\hline $\mathrm{AQ} 3$ & $\begin{array}{l}\text { Please provide an English translation of the title in the reference "Dupon (1993)", } \\
\text { as per journal style } \\
\text { [http://www.tandf.co.uk/journals/authors/style/reference/tf_APA.pdf]. }\end{array}$ \\
\hline AQ4 & $\begin{array}{l}\text { Please provide an English translation of the title in the reference "Felicísimo and } \\
\text { Muñoz (2012)", as per journal style } \\
\text { [http://www.tandf.co.uk/journals/authors/style/reference/tf_APA.pdf]. }\end{array}$ \\
\hline AQ5 & $\begin{array}{l}\text { Please provide an English translation of the title in the reference "Florence (1997)", } \\
\text { as per journal style } \\
\text { [http://www.tandf.co.uk/journals/authors/style/reference/tf_APA.pdf]. }\end{array}$ \\
\hline AQ6 & $\begin{array}{l}\text { Please provide an English translation of the title in the reference "Florence (2007)", } \\
\text { as per journal style } \\
\text { [http://www.tandf.co.uk/journals/authors/style/reference/tf_APA.pdf]. }\end{array}$ \\
\hline AQ7. & $\begin{array}{l}\text { Please provide missing city for the "MacArthur and Wilson (1967)" references list } \\
\text { entry. }\end{array}$ \\
\hline AQ8 & $\begin{array}{l}\text { Please provide missing page numbers for the "Royo et al. (2011)" references list } \\
\text { entry. }\end{array}$ \\
\hline
\end{tabular}




\section{How to make corrections to your proofs using Adobe Acrobat/Reader}

Taylor \& Francis offers you a choice of options to help you make corrections to your proofs. Your PDF proof file has been enabled so that you can edit the proof directly using Adobe Acrobat/Reader. This is the simplest and best way for you to ensure that your corrections will be incorporated. If you wish to do this, please follow these instructions:

1. Save the file to your hard disk.

2. Check which version of Adobe Acrobat/Reader you have on your computer. You can do this by clicking on the "Help" tab, and then "About".

If Adobe Reader is not installed, you can get the latest version free from http:/get.adobe.com/ reader/.

3. If you have Adobe Acrobat/Reader 10 or a later version, click on the "Comment" link at the righthand side to view the Comments pane.

4. You can then select any text and mark it up for deletion or replacement, or insert new text as needed. Please note that these will clearly be displayed in the Comments pane and secondary annotation is not needed to draw attention to your corrections. If you need to include new sections of text, it is also possible to add a comment to the proofs. To do this, use the Sticky Note tool in the task bar. Please also see our FAQs here: http://journalauthors.tandf.co.uk/production/index.asp.

5. Make sure that you save the file when you close the document before uploading it to CATS using the "Upload File" button on the online correction form. If you have more than one file, please zip them together and then upload the zip file.

If you prefer, you can make your corrections using the CATS online correction form.

\section{Troubleshooting}

Acrobat help: http://helpx.adobe.com/acrobat.html

Reader help: http://helpx.adobe.com/reader.html

Please note that full user guides for earlier versions of these programs are available from the Adobe Help pages by clicking on the link "Previous versions" under the "Help and tutorials" heading from the relevant link above. Commenting functionality is available from Adobe Reader 8.0 onwards and from Adobe Acrobat 7.0 onwards.

Firefox users: Firefox's inbuilt PDF Viewer is set to the default; please see the following for instructions on how to use this and download the PDF to your hard drive: http://support.mozilla.org/en-US/kb/ view-pdf-files-firefox-without-downloading-them\#w_using-a-pdf-reader-plugin 


\title{
Cyclones influence native plant diversity on 22 remote high islands of French Polynesia and Pitcairn (eastern Polynesia)
}

\author{
Sébastien Larrue* \\ GEOLAB $\Omega$ boratoire de géographie physique et environnementale, Clermont Université, \\ Clermont-Ferrand, France
}

(Received 26 February 2014; accepted 10 July 2014)

\begin{abstract}
I examined the relative influence of eight spatial characteristics on native plant diversity in 22 volcanic high islands of eastern Polynesia. The characteristics used as potential predictors in this study included island area, highest elevation, distance to the nearest continent, distance to the nearest archipelago, distance to the nearest similar island, index of isolation, distance to the largest and highest island of Tahiti, and distance to the "cyclonic alley." Among characteristics studied, native plant diversity (indigenous and endemic species) was primarily linked with the island area and highest elevation of the islands. Contemporary cyclones were an important predictor of indigenous plant diversity in the remote islands surveyed. In the study area, this result suggests that cyclones, moving from the west Pacific Ocean basin to the eastern Polynesian islands, have provided more indigenous species to the remote high islands located close to the cyclonic alley. Isolation did not appear as a significant predictor of native plant diversity in the high islands surveyed, possibly due to a stepping-stone-island effect and the proximity of the cyclonic alley. These findings suggest that isolation could be tempered by a cyclonic-transport-flow effect in the study area, thus reducing the effective distance of the remote islands from the mainland source pool for seed dispersal.
\end{abstract}

Keywords: abiotic factors; cyclone alley; eastern Polynesia; island biogeography; native plant diversity

\section{Introduction}

How species reach islands and which factors influence native plant diversity are of particular interest to biogeographers. The relationships between the spatial characteristics of islands and native species richness have been studied by many workers (e.g. Gilbert, 1980; Rosenzweig, 1995; Whittaker \& Fernández-Palacios, 2007), following MacArthur and Wilson (1967). The contrast in topography and substrata of high islands vs. coral atolls, as well as the total rainfall and average temperatures, are some factors influencing species richness on islands (Mueller-Dombois, 2002; Stoddart, 1992). However, Kalmar and Currie (2006) underlined that the literature addressing factors that determine species richness on islands contains an important gap, possibly due to different scales of analysis (Whittaker, Willis, \& Field, 2001).

In particular, the size, elevation, or isolation of high islands are important features to explain diversity and endemism (e.g. Ackerman, Trejo-Torres, \& Crespo-Chuy, 2007; Diamond, 1975; McMaster, 2005; Paulay, 1994; Preston, 1962a, 1962b;

*Email: sebastien.larrue@univ-bpclermont.fr 
Rosenzweig, 1995). For example, Hamilton, Rubinoff, Barth, and Bush (1963) and Johnson and Raven (1973) concluded that elevation is significant for plant diversity in the Galapagos Archipelago. On the islands of the northeast coast of Australia, Buckley (1985) showed the influence of both elevation and substrate type on plant diversity. Losos and Schluter (2000) demonstrated that the size of the island influences the speciation, whereas Rosindell and Phillimore (2011) showed that speciation is strongly influenced by isolation. On the other hand, some results on bird diversity at global scales showed that this was best predicted on islands by a combination of isolation and/or size with other simple contemporary abiotic factors (Kalmar \& Currie, 2006). Felicísimo and Muñoz (2012), and Muñoz, Felicísimo, Cabezas, Burgaz, and Martinez (2004) showed that floristic similarities, at large geographic scale, were better correlated with contemporary trade wind connectivity than with geographic isolation in the Southern Hemisphere. These studies support the hypothesis that wind is an important long-distance dispersal vehicle for native plants in the South Pacific Ocean. In addition, ocean currents or tropical cyclones could also be important to predict native plant diversity on the remote Pacific islands (e.g. Daehler, 2006; Dahl, 1984).

The physical disturbances of forest ecosystems by tropical cyclones have been described by many authors (e.g. Basnet, Likens, Scatena, \& Lugo, 1992; Pascarella, Aide, \& Zimmerman, 2004; Simberloff, 1995; Vandermeer, de la Cerda, Boucher, Perfecto, \& Ruiz, 2000; Walker, 1991) and specifically their impacts on lowland rain forests of tropical islands (Hastings, 1990; Kerr, 2000; Lugo, 2008). Damages reported ranged from moderate effects, i.e. broken branches, defoliation, and tree falls (e.g. Elmqvist, Rainey, Pierson, \& Cox, 1994; Turton \& Siegenthaler, 2004), to important effects with high tree mortality (Franklin, Drake, McConkey, Tonga, \& Smith, 2004; Lugo, 2008; Zimmerman et al., 1994). Some tree species are more vulnerable to cyclonic winds (Burslem, Whitmore, \& Brown, 2000; Curran et al., 2008; Elmqvist et al., 1994; Herbert, Fownes, \& Vitousek, 1999) and this selective mortality influences structure and composition of the tropical rain forests in the long term (Keppel, Buckley, \& Possingham, 2010). Indeed, lower canopies and higher tree densities on the windward coast of Madagascar (de Gouvenain \& Silander, 2003) and in Southwest Pacific islands (Keppel et al., 2010) have been related to the high frequency of cyclones in these regions. In the long term, a high frequency of cyclones disturbance drives diversity not only in tree communities (de Gouvenain \& Silander, 2003; Keppel et al., 2010), but also in nonarborescent understory communities where an increasing diversity of ferns and vines was observed in Puerto Rico (Royo, Scalley, Moya, \& Scatena, 2011). These findings contrast with prior assumptions, e.g. by Brokaw and Walker (1991), who reported that cyclones do not have a long-lasting impact on forest structure and composition, and support the hypothesis that cyclone disturbance is an important factor controlling, at least partially, forest structure and plant diversity in tropical islands. In addition, some studies reported that high frequency of storm-induced disturbance may impact species richness in the Bahamian islands (Morrison, 2002), while Keppel et al. (2010) observed no significant effect of cyclone frequency on species diversity in the Southwest Pacific islands. However, no quantitative information is available about the influence of these long-distance dispersal vehicles on native species richness in eastern Polynesia.

45 In this study, several predictors were tested to explain the native plant diversity in the remote islands of eastern Polynesia. Among these predictors, I closely examined if the number of native plants on 22 remote high volcanic islands was related to the distance to the "cyclonic alley" (Figure 1). Here, the pathway of disturbance is explicitly considered as a spatial factor. I hypothesized that native species richness on the remote 


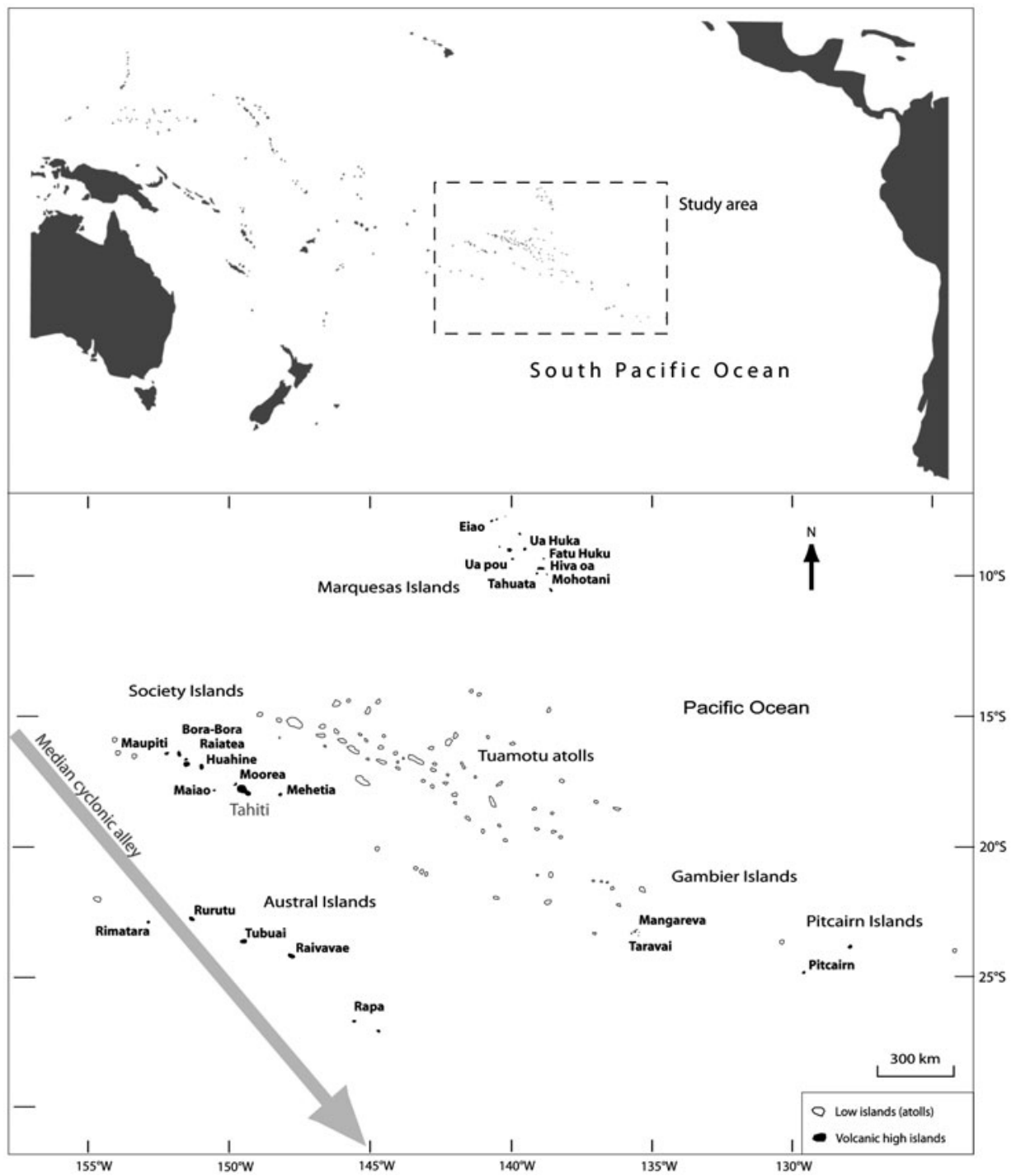

Figure 1. Location of the volcanic high islands in French Polynesia and the Pitcairn group (eastern Polynesia).

Notes: The 22 volcanic high islands surveyed in this paper appear in bold. The mapped "cyclonic alley" corresponds to the median cyclonic pathway followed by cyclones and tropical storms in the oceanic Economic Exclusive Zone (EEZ) of French Polynesia (for details see Etienne, 2012; Larrue \& Chiron, 2010).

high islands of eastern Polynesia could be inversely related to the distance of these islands from the tropical cyclone pathway.

\section{Materials and methods}

\section{Study area and islands surveyed}

The study area corresponds to the geographic center of eastern Polynesia, which is formed by diverse volcanic and coral islands with marked geographic isolation in the 
vast South Pacific Ocean. Eastern Polynesia is a large phytogeographical sub-region of Polynesia (Mueller-Dombois \& Fosberg, 1998). It includes the five archipelagos of French Polynesia (i.e. the Society Islands, the Austral Islands, the Gambier Islands, the Marquesas Islands, and the Tuamotu atolls), and the archipelagos of the Cook Islands, the Pitcairn Islands, and Easter Island (Mueller-Dombois \& Fosberg, 1998). With an island area of $1042 \mathrm{~km}^{2}$ and a summit at $2242 \mathrm{~m}$ asl, the volcanic island of Tahiti (Society Islands, French Polynesia) is both the biggest and highest island of eastern Polynesia.

The islands surveyed consist of 22 volcanic high islands scattered in the tropical Pacific Ocean between $7^{\circ} 59^{\prime} 40.8^{\prime \prime} \mathrm{S}-25^{\circ} 04^{\prime} 08.5^{\prime \prime} \mathrm{S}$ and $128^{\circ} 19^{\prime} 11.02^{\prime \prime} \mathrm{W}-154^{\circ} 38^{\prime}$ $33.06^{\prime \prime} \mathrm{W}$. Twenty-one of the islands are found in the volcanic archipelagos of French Polynesia, and one is located in the Pitcairn group (Figure 1). The islands surveyed represent a total terrestrial area of $1306 \mathrm{~km}^{2}$, with a mean size of $59.3 \mathrm{~km}^{2}$ and a mean elevation of $603 \mathrm{~m}$. These small oceanic islands emerged from the basaltic bottom of the ocean (called a "hotspot") and were consequently never connected to a mainland (Allison \& Eldredge, 1999; Mueller-Dombois, 2002; Nunn, 1994). These islands are among the most isolated in the world and native species in eastern Polynesia mark the "easternmost limit of the range of a very large number of genera in Malaysia and Pacific Ocean islands" (Meyer, 2004, p. 363). These islands are hit by cyclones, but the 20 average frequency of disturbance (cyclone by year) is very low in the study area, i.e. 0.12 per year between 1970 and 2009 (Larrue \& Chiron, 2010).

\section{Methods}

\section{Characteristics of islands analyzed in this study}

According to their potential influence on the native diversity, the following characteristics of the islands were selected: distance of each island to the nearest continent, distance to the nearest archipelago, distance to the nearest similar island, distance to Tahiti, distance to the cyclonic alley, isolation, island area, and highest elevation. Each measurement of distance was performed with a Geographic Information System (GIS Mapinfo ${ }^{\circledR}$ Professional version 10, WGS 1984 projection). With regard to the characteristic distance to Tahiti, note that this both largest and highest island was chosen in relation to the potential "stepping-stone effect" reported by workers in some other archipelagos (MacArthur \& Wilson, 1967; McMaster, 2005).

The data for island area and highest elevation were obtained from the Atlas of French Polynesia (Dupon, 1993) and United Nations Environment Programme (UNEP) island database (http://islands.unep.ch). The index of isolation was calculated as defined by the UNEP index of isolation (Dahl, 1998) as:

$$
I_{i}=\left(\sqrt{d_{i}}+\sqrt{d_{a}}+\sqrt{d_{c}}\right),
$$

where $d_{i}$ is the distance to the nearest equivalent or larger island, $d_{a}$ the distance to the nearest archipelago, and $d_{c}$, the distance to the nearest continent (i.e. North America, South America, Australia, or New Guinea).

\section{Selection of 22 volcanic high islands}

The selection of the islands surveyed was made in two steps. First, the volcanic high islands $\left(>0.5 \mathrm{~km}^{2}\right)$ of French Polynesia and Pitcairn group were listed based on the 
Atlas of French Polynesia (Dupon, 1993) and the UNEP island database (http://islands. unep.ch). Thirty-three volcanic high islands were found in the study area (Figure 1). Second, it is well known that island area and highest elevation are both important predictors for species richness on islands (e.g. Ackerman et al., 2007; McMaster, 2005; Triantis, Mylonas, Lika, \& Vardinoyannis, 2003; Whittaker \& Fernández-Palacios, 2007; Wright, 1983), and island isolation is an explanatory factor for diversity (e.g. Dahl, 1984; Meyer, 2004). Therefore, I used Multiple Correspondence Analysis (MCA, XLStat ${ }^{\circledR}$ [version 2007.6] software) with criteria of "island area," "highest elevation," and "isolation" to test the similarity of the volcanic high islands found in the study area (Figure 2). Then, an equal number of islands with a similar value of "island area," "highest elevation," and "isolation" were selected in pairs. These islands are similar in most respects, but present a maximum range of distance "to the cyclonic alley" (Table 1). Thus, 22 volcanic high islands scattered in the study area were selected and Spearman's correlation coefficients were used to confirm the independence of "island area" and "highest elevation" against the other characteristics in the islands selected (Figure 3).

\section{Diversity of native plant species on the high islands}

For each volcanic high island, I recorded both plant status and number of native plants listed in the online database Nadeau (Florence, Chevillotte, Ollier, \& Meyer, 2007).

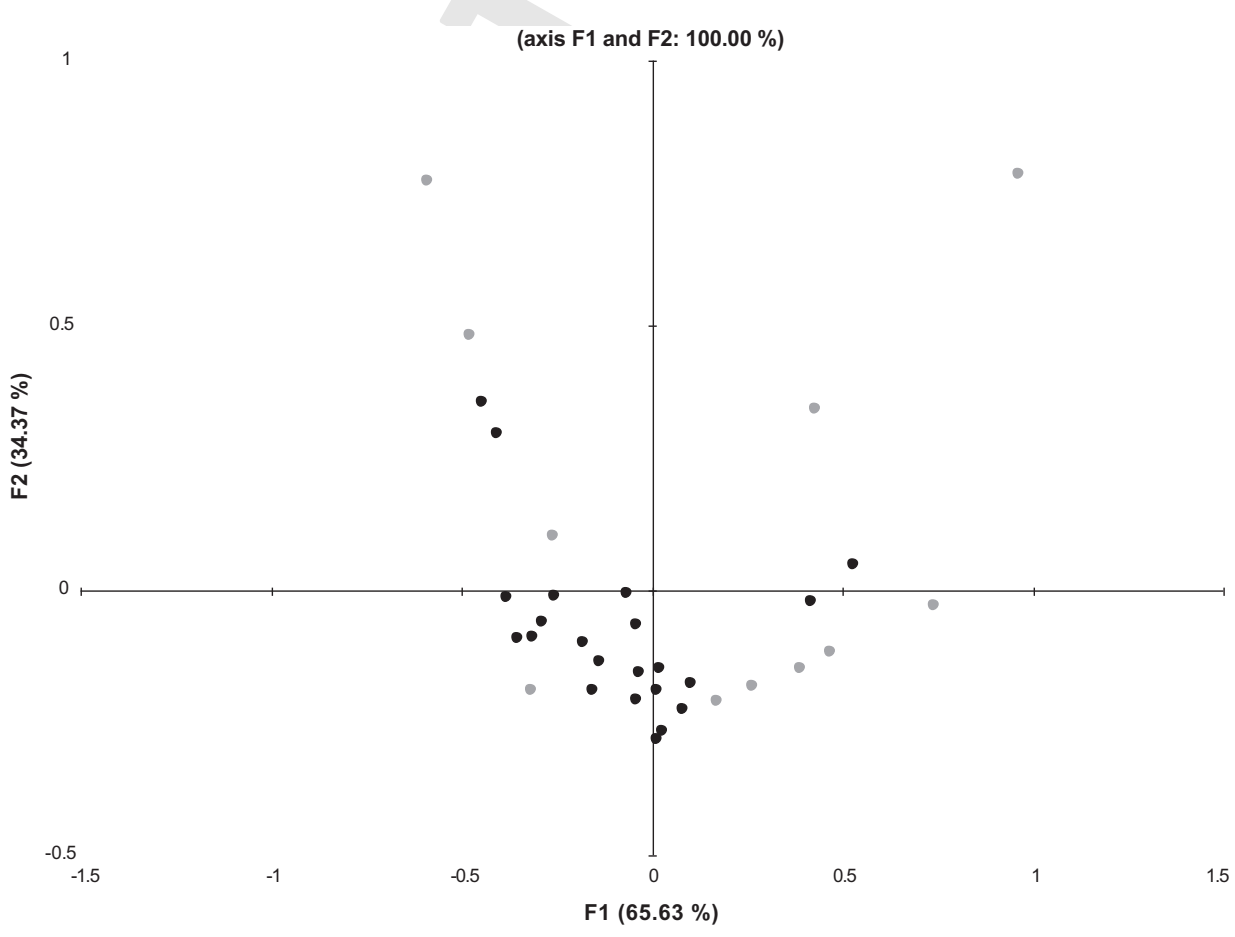

Figure 2. Multiple Correspondence Analysis (MCA) of the 33 volcanic high islands found in French Polynesia and the Pitcairn group with "island area," "highest elevation," and "isolation." Notes: MCA shows an important range of these characteristics. Black circles correspond to the 22 high islands selected for this study. 


\begin{tabular}{|llc|}
\hline TPHY 946808 & Initial & CE: AJ QA: MA \\
4 August 2014 & Coll: QC:
\end{tabular}

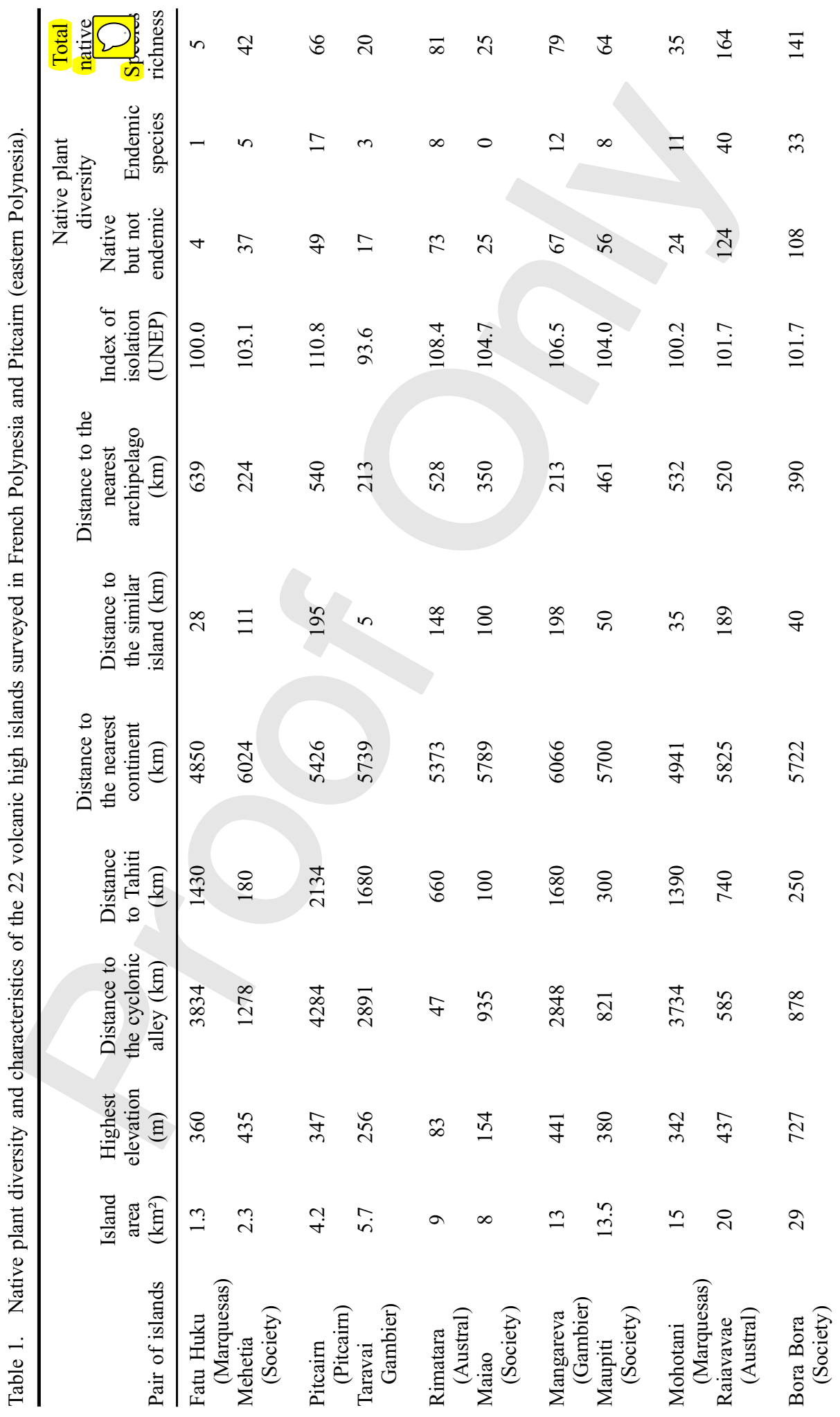


\begin{tabular}{|llc|}
\hline TPHY 946808 & Initial & CE: AJ QA: MA \\
4 August 2014 & Coll: QC:
\end{tabular}

Physical Geography 7

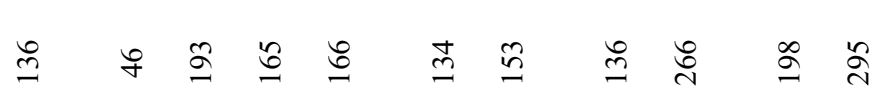

ช ป

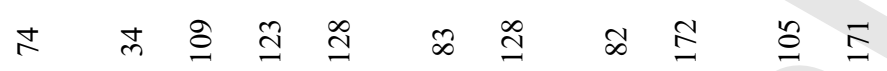

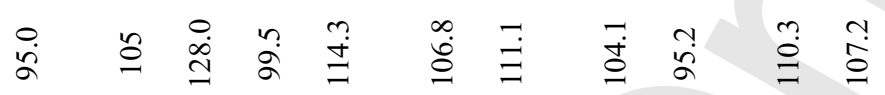

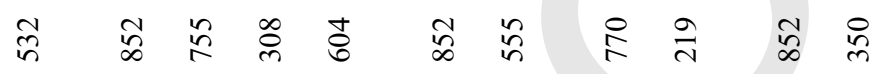

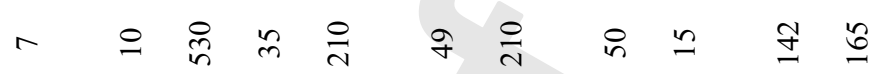

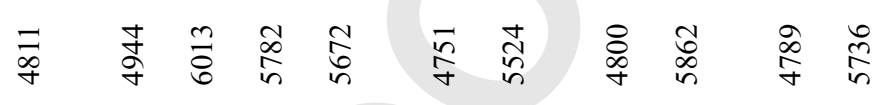

ஜ

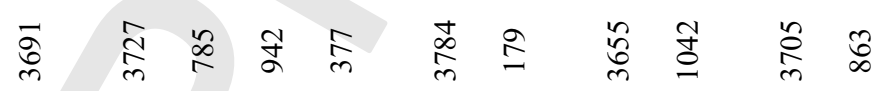

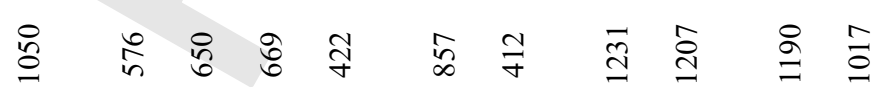

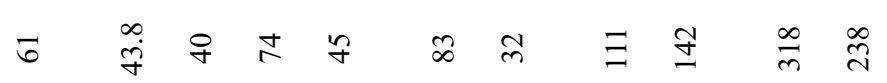

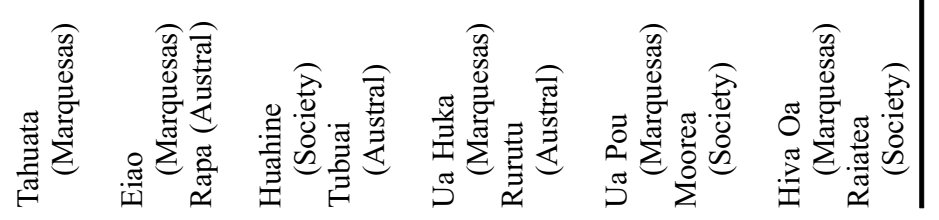




\begin{tabular}{|lcc|}
\hline TPHY 946808 & \multirow{2}{*}{ Initial } & CE: AJ QA: MA \\
4 August 2014 & & Coll: QC: \\
\hline
\end{tabular}

S. Larrue
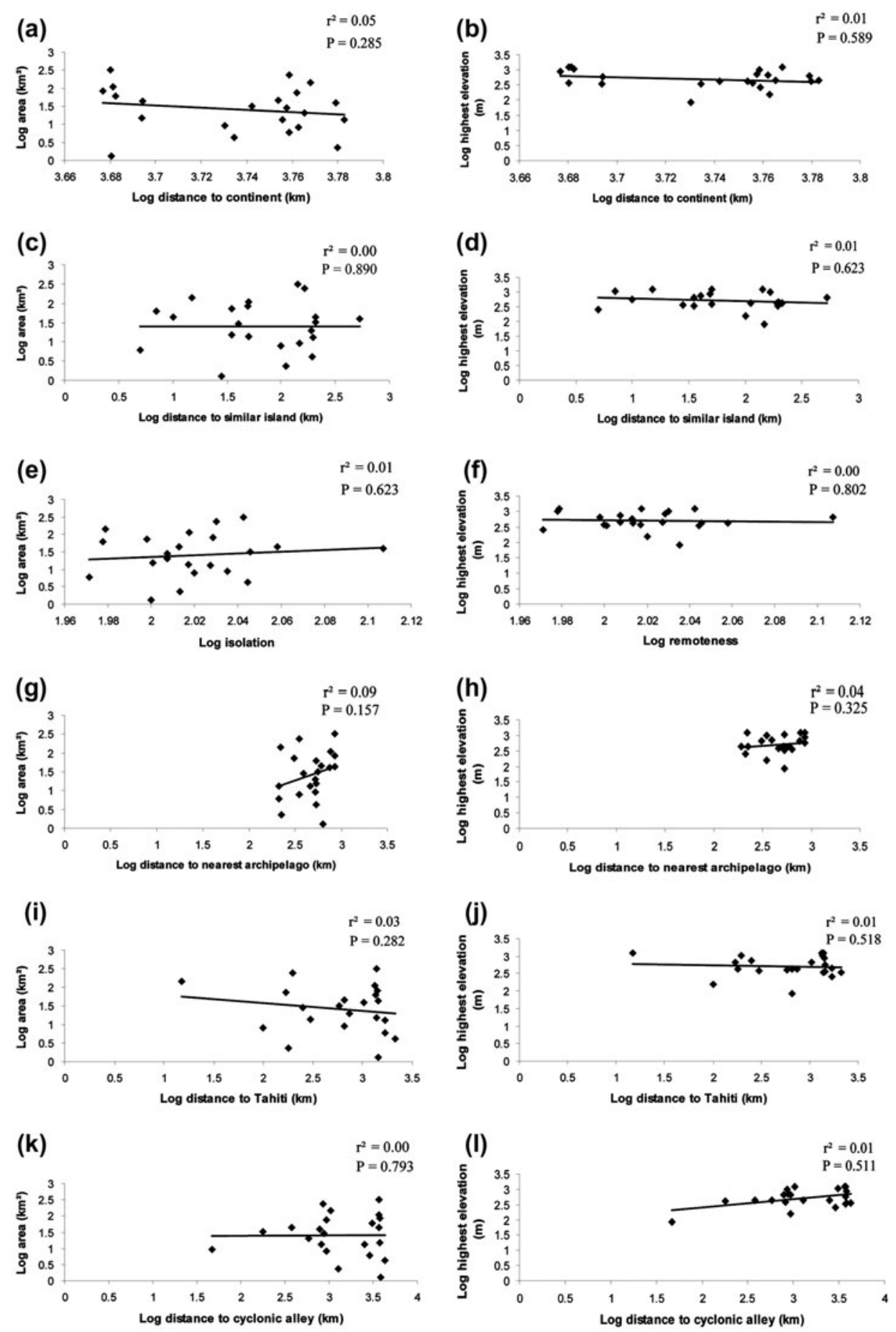

Figure 3. (a-1) Regre s of "island area" and "highest elevation" against the other independent variables for the 22 high islands surveyed (eastern Polynesia). 
According to the database, the status of native species was listed as indigenous (i.e. native but not endemic) or endemic. Endemic species include four levels of endemism (Florence et al., 2007): (1) native species only found on an island and called "endemic insular," (2) species found in one archipelago and named "endemic archipelago," (3) species observed in the five archipelagos of French Polynesia and called "endemic French Polynesia," and (4) species that can be observed on the volcanic high islands of French Polynesia, the Pitcairn group, and Cook Islands, called the "endemic in eastern Polynesia."

\section{Correlation between native plant diversity and characteristics of the 22 high islands}

I tested the statistical correlations between each characteristic of the islands and native plant diversity (Spearman's correlation coefficients, Xlstat software). The statistical link between the native species richness and the distance to the cyclonic alley was closely observed.

\section{Results}

\section{Native species richness on the 22 volcanic high islands}

The indigenous species range from 4 to 172 species per island, and the total endemic species range between 0 and 124 species per island (Table 1). Indigenous and endemic status represent 68.6 and $31.4 \%$ of the native species found on the high islands surveyed, respectively (Figure 4). Figure 5 provides a detail of the native species richness found in the islands surveyed.

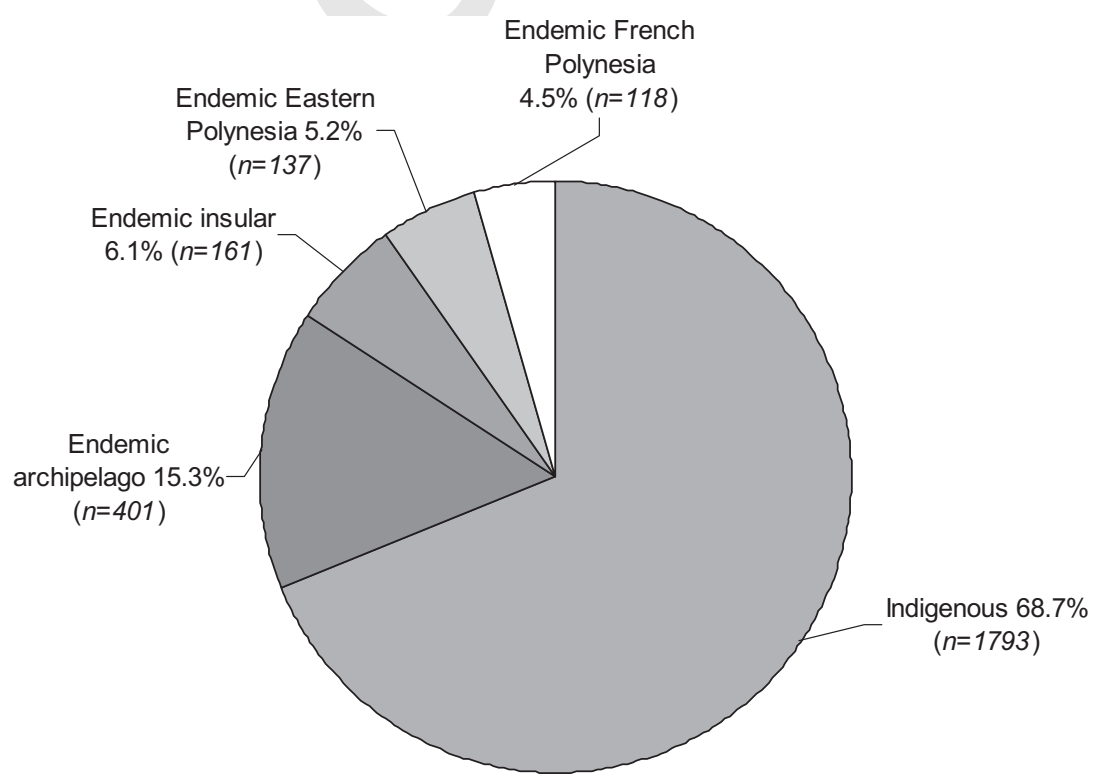

Figure 4. Distribution of native plants relative to status on the 22 high islands of French Polynesia and Pitcairn (eastern Polynesia).

Note: Note that $n$ corresponds to the total citations of the status recorded on the 22 high islands. 


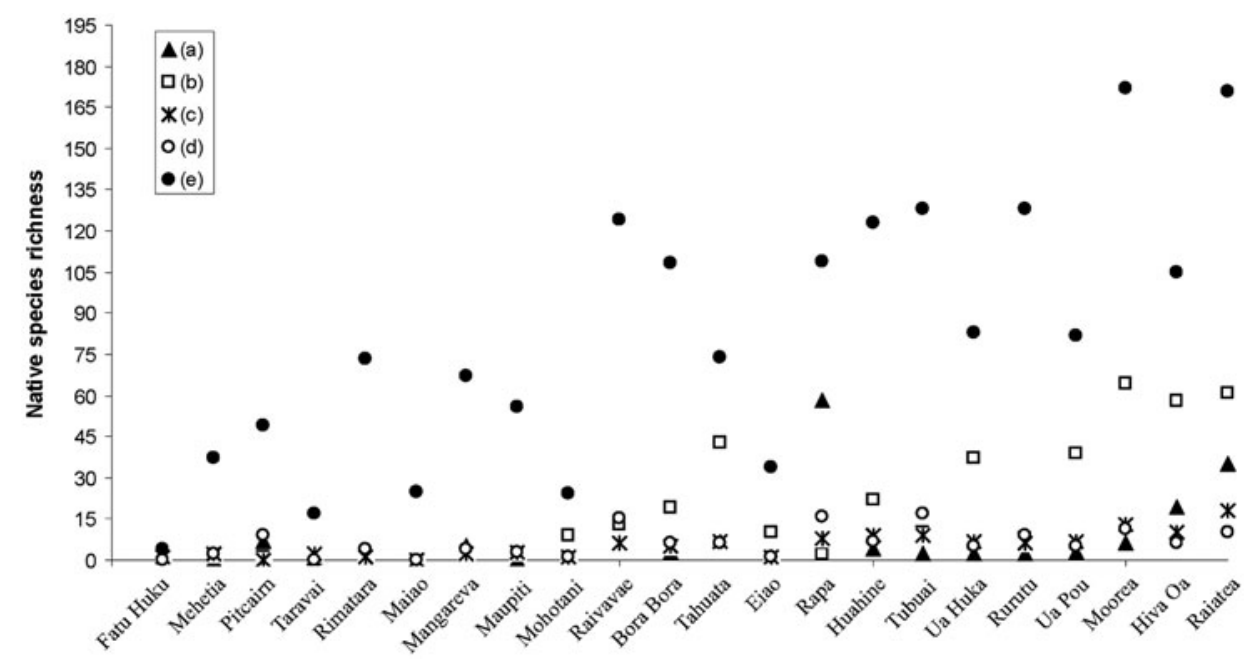

Figure 5. Native species richness in the 22 islands surveyed with: (a) "endemic insular," (b) "endemic archipelago," (c) "endemic French Polynesia," (d) "endemic in eastern Polynesia," and (e) indigenous (native but not endemic).

\section{Characteristics of the islands and correlation coefficients with the native species}

\section{Endemic species}

All endemic species were strongly correlated with island area and the highest elevation of the islands (Table 2). The endemic species of eastern Polynesia were correlated with both the distance to the nearest similar island $\left(r^{2}=0.291, p<0.01\right)$ and distance to the cyclonic alley (inverse correlation, $r^{2}=0.194, p<0.05$ ). I did not observe any significant correlation between the endemic species and the other characteristics (Table 2).

\section{Indigenous species}

The island area and highest elevation were strongly correlated with the indigenous species richness on the islands (Figure 6(a)-(b)). Then, the results showed inverse correlations between the indigenous species and both distance to the cyclonic alley

able 2. Correlation between the characteristics of the islands and the endemic species on the 22 volcanic high islands of French Polynesia and Pitcairn (Spearman's correlation coefficients).

Characteristics of the high islands $(n=22)$

Area $\left(\mathrm{km}^{2}\right)$

Highest elevation (m)

Distance to nearest continent $(\mathrm{km})$

Distance to nearest similar island $(\mathrm{km})$

Distance to nearest archipelago $(\mathrm{km})$

Index of isolation (remoteness UNEP)

Distance to Tahiti $(\mathrm{km})$

Distance to cyclonic alley $(\mathrm{km})$
Endemic species

\begin{tabular}{cccc}
\hline Insular & Archipelago & $\begin{array}{c}\text { French } \\
\text { Polynesia }\end{array}$ & $\begin{array}{c}\text { Eastern } \\
\text { Polynesia }\end{array}$ \\
\hline $0.53^{*}$ & $0.92^{* *}$ & $0.84^{* *}$ & $0.54^{* *}$ \\
$0.58^{* *}$ & $0.86^{* *}$ & $0.77^{* *}$ & $0.45^{*}$ \\
0.15 & -0.23 & 0.05 & 0.20 \\
0.37 & -0.14 & 0.12 & $0.54^{* *}$ \\
0.03 & 0.21 & 0.05 & 0.11 \\
0.27 & -0.07 & 0.09 & 0.40 \\
-0.00 & -0.27 & -0.37 & -0.27 \\
-0.11 & 0.00 & -0.20 & $-0.44^{*}$ \\
\hline
\end{tabular}


(a)

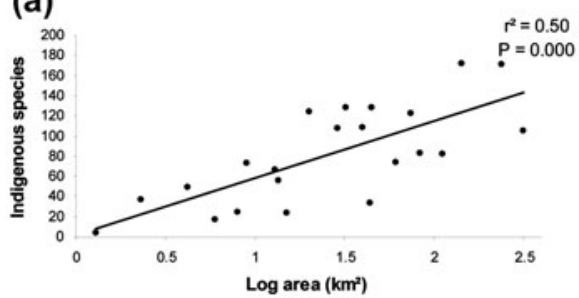

(c)

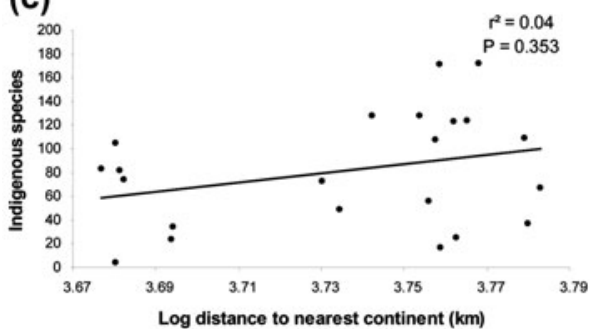

(e)

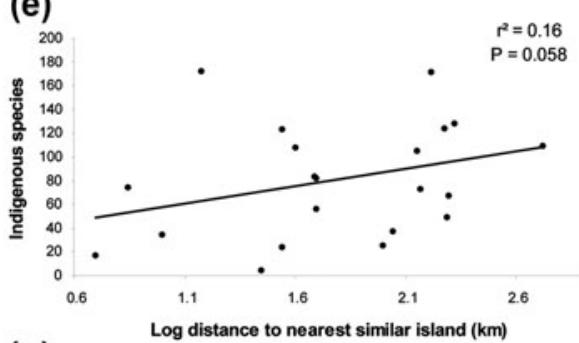

(g)

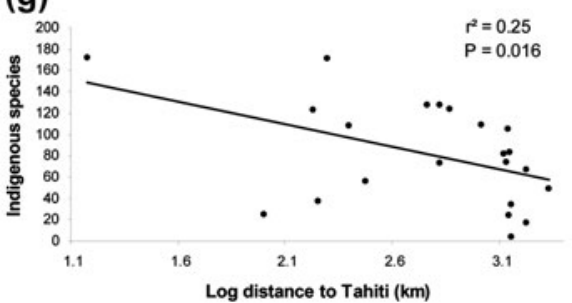

(b)

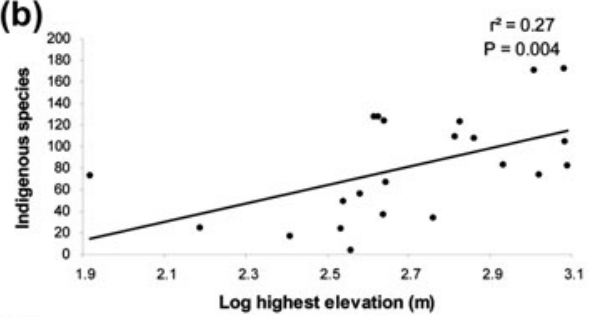

(d)

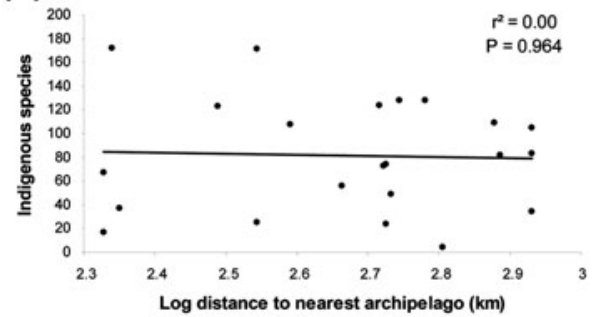

(f)

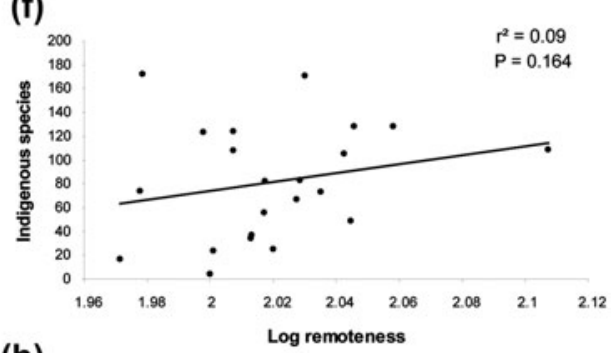

(h)

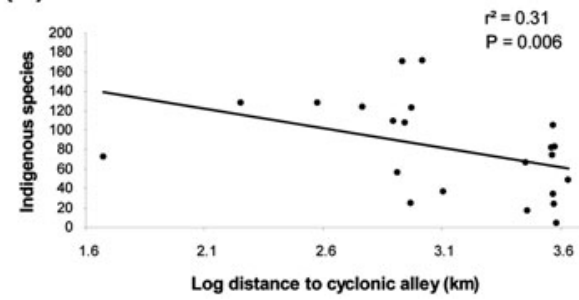

Figure 6. (a-h) Indigenous species richness compared to the characteristics of the 22 high islands with: (a) island area, (b) highest elevation, (c) distance to the nearest continent, (d) distance to the nearest archipelago, (e) distance to the nearest similar island, (f) isolation, (g) distance to Tahiti, and (h) distance to the cyclonic alley.

$\left(r^{2}=0.311, p<0.01\right)$ and distance to Tahiti $\left(r^{2}=0.256, p<0.05\right)$, (Figure 6(g) $-(\mathrm{h})$, respectively). No correlation was found between the indigenous species and the distances to the nearest continent, nearest archipelago, nearest similar island, and isolation (Figure 6(c)-(f)).

\section{Discussion}

\section{Which factors influence native plant diversity?}

On the 22 remote volcanic high islands, the number of endemic and indigenous species was strongly related to island area and highest elevation (Table 2 and Figure 5 (a)-(b)). 
These results are in agreement with previous studies, which demonstrated that island area and highest elevation are both important predictors for plant diversity on remote islands (Ackerman et al., 2007; Hamilton et al., 1963; Johnson \& Raven, 1973; McMaster, 2005). Largest and highest islands harbor more habitat diversity and tend to contain more native species, and vice versa. This species-area relationship may be explained by the theory of insular biogeography and confirms the importance of (1) area effects with limited ecological niche capacity, habitat diversity, and heterogeneity, and (2) fluctuation of the equilibrium between the rate of immigration and extinction (MacArthur \& Wilson, 1967; Morand, 2000; Ricklefs \& Lovette, 1999; Triantis et al., 10 2003; Whittaker \& Fernández- Palacios, 2007).

Conversely, whereas isolation explains why remote islands support fewer species, possibly due to lower immigration rates and a poor rescue (MacArthur \& Wilson, 1967; Whittaker \& Fernández-Palacios, 2007), no statistically significant correlation was found between native plant diversity and isolation for the 22 islands studied

15 (Table 2 and Figure 6(f)). There is no doubt that the islands of French Polynesia and Pitcairn are among the most remote in the world (Table 1). However, isolation effects (e.g. lower species immigration with increasing distance from the continent) could be tempered by other factors such as inherent differences in plant dispersibility (Daehler, 2006), or a stepping-stone-island effect, which represents the capacity of a large island 20 to increase considerably the flow of propagules to nearby islands (e.g. MacArthur \& Wilson, 1967; McMaster, 2005). I observed an inverse correlation between the indigenous species richness on the islands and the distance to Tahiti $\left(r^{2}=0.256, p=0.016\right.$; Figure $6(\mathrm{~g})$ ). This result demonstrates that the biggest and highest island of Tahiti influences the spatial distribution of indigenous species in the islands. Consequently, the 25 large island of Tahiti can be viewed as a "stepping-stone island" and a provider of native species to the surrounding islands in a remote environment.

\section{How can the relationship between native plant diversity and distance to the cyclonic alley be explained?}

Whereas endemic species tend to lose their dispersion capacity with time on remote 30 islands (Carlquist, 1974; Florence, 1997), I observed an inverse correlation between endemic species at the eastern Polynesia level and DCA, even though this correlation was weak (Table 2). These endemic species have spread in the Cook Islands, French Polynesia, and the Pitcairn group, and cyclones could play a role in the spatial distribution of these species in the geographic region of eastern Polynesia.

35 More important, the indigenous species richness was inversely related to the distance to the cyclonic alley, showing that species richness in the islands decreases with the increasing distance to the cyclonic alley (Figure 6(h)). Indigenous species on the islands of French Polynesia and the Pitcairn group mainly originate from the IndoMalayan Peninsula located to the northwest of the islands studied (Van Balgooy, 1993) and it is commonly accepted that the decrease in species richness from west to east on the Pacific islands is mainly linked to the increasing distance of the remote islands from the mainland source pool of Indo-Malayan and Austro-Melanesian regions (Dahl, 1980, 1984; Ellison, 2009; Van Balgooy, 1993; Van Balgooy, Hovenkamp, \& van Welzen, 1996). Data on native plant dispersibility for the study area (Florence, 1997, 2007; Florence, Waldren, \& Chepstow-Lusty, 1995; Kingston, 2001) show that anemochory for native species represents $46 \%$ in the Austral and 50\% in the Society Islands, vs. 43, 34, and 19\%, in the Marquesas, Gambier, and Pitcairn group, respectively (Table 3). 


\begin{tabular}{|lcc|}
\hline TPHY 946808 & \multirow{2}{*}{ Initial } & CE: AJ QA: MA \\
4 August 2014 & & Coll: QC: \\
\hline
\end{tabular}

Physical Geography

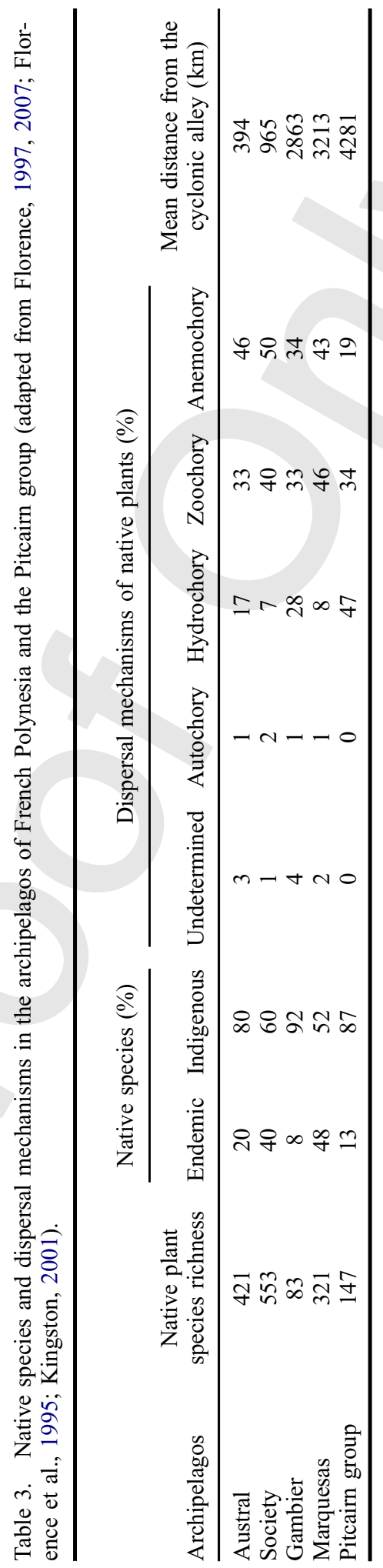


Considering that indigenous species represent the greatest percentage of native plants in the archipelagos cited above (Table 3), data on dispersal mechanisms for native plants chiefly provide a picture of indigenous dispersion.

The propagules of wind-dispersed species in eastern Polynesia would have had to move against the easterlies above the Pacific Ocean in order to disperse by anemochory from the mainland source pool to eastern Polynesia. Some authors have suggested that wind-dispersed species reached the islands by using the high jet stream blowing from west to east above the easterlies (Carlquist, 1974; Drake, 1992; Florence, 1997, 2007) or during the Quaternary glaciations and strong El Niño events when the easterlies were reversed (i.e. blowing from west to east, Wright, Yong, Dawson, Whittaker, \& Gardner, 2000). Here, I identify a complementary possibility to explain the long-distance dispersal of native plants in the eastern Pacific basin. Indeed, several authors identified main trajectories of contemporary cyclones in this region, moving from northwest to southeast (Etienne, 2012; Larrue \& Chiron, 2010; Woodroffe \& Stoddart, 1992), which are congruent with the direction of native species dispersal. Moreover, native plants on the archipelagos situated close to the cyclonic alley tend to record a higher level of plant dispersibility by anemochory than those far away from the cyclonic alley (Table 3). Cyclones are temporal disturbances that interact only during short time spans on islands, but the location of islands in respect to the pathway of disturbances has to be taken into account at the global scale to better understand the spatial pattern of native species within islands. This result is in agreement with the hierarchical theory of species diversity, which considers that diversity is driven by a combination of phenomena occurring at various spatiotemporal scales (Whittaker et al., 2001).

\section{Conclusion}

On the remote high volcanic islands studied, native plant diversity is firstly related to island area and the highest elevation. As reported by many authors, this confirms that the elevation and size of the islands are important predictors for native plant diversity on the remote tropical islands. Here, distance to the cyclonic alley clearly contributed to explain native species richness.

It was demonstrated that the geographical distance to the cyclonic alley was an important predictor of the spatial pattern of the indigenous species on the islands. Furthermore, no correlation between native plant diversity and isolation of the islands was found, possibly due to both the st phe-stone-island effect of Tahiti, and a cyclonictransport-flow effect of distance to tII cyclonic alley. Indeed, cyclonic winds may be able to disperse seeds from the mainland source pool to the islands surveyed. These findings suggest that cyclones can increase native species richness in extreme remote islands by increasing the flow of propagules from the source pool region to the remote islands located close to the cyclonic alley, thus reducing the "distance" of the islands to the mainland source pool.

\section{Acknowledgments}

I am grateful to the "Ministère de l'Ecologie" (Paris, France) for their financial support for the mission in French Polynesia. I want to thank my colleagues Christophe Corona and Johannes Steiger (CNRS, UMR 6042, GEOLAB, France) for providing useful comments on an early version of this paper and revising the English. 


\section{References}

Ackerman, J. D., Trejo-Torres, J. C., \& Crespo-Chuy, Y. (2007). Orchids of the West Indies: Predictability of diversity and endemism. Journal of Biogeography, 34, 779-786.

Allison, A., \& Eldredge, L. (1999). Polynesia and Micronesia. In R. A. Mittermeier, N. Myers, N. P. Robles-Gil, \& C. G. Mittermeier (Eds.), Hotspots. Earth's biologically richest and most endangered terrestrial ecoregions (pp. 390-401). Cemex and Conservation International.

Basnet, K., Likens, G. E., Scatena, F. N., \& Lugo, A. E. (1992). Hurricane Hugo: Damage to a tropical rain forest in Puerto Rico. Journal of Tropical Ecology, 8, 47-55.

Brokaw, N. V. L., \& Walker, L. R. (1991). Summary of the effects of Carribean hurricanes on vegetation. Biotropica, 23, 442-447.

Buckley, R. C. (1985). Distinguishing the effects of area and habitat types on Island plant species richness by separating floristic elements and substrate types and controlling for island isolation. Journal of Biogeography, 12, 527-535.

Burslem, D. F. R. P., Whitmore, T. C., \& Brown, G. C. (2000). Short-term effects of cyclone impact and long-term recovery of tropical rain forest on Kolombangara, Solomon Islands. Journal of Ecology, 88, 1063-1087.

Carlquist, S. (1974). Island biology. New York, NY: Columbia University Press.

Curran, T. J., Brown, R. L., Edwards, E., Hopkins, K., Kelley, C., McCarthy, E., Pounds, E., Solan, R., \& Wolf, J. (2008). Plant functional traits explain interspecific differences in immediate cyclone damage to trees of an endangered rainforest community in North Queensland. Austral Ecology, 33, 451-461.

Daehler, C. C. (2006). Invasibility of tropical islands by introduced plants: Partitioning the influence of isolation and propagule pressure. Preslia, 78, 361-374.

Dahl, A. L. (1980). Regional ecosystems survey of the South Pacific. SPC Technical Paper No. 179. SPC. Noumea: IUCN.

Dahl, A. L. (1984). Biogeographical Aspects of Isolation in the Pacific. Ambio, 13, 302-305.

Dahl, A. L. (1998) Island directory, United Nations Environment Programme. Retrieved from $\mathrm{http} /$ /islands.unep.ch

de Gouvenain, R. C., \& Silander, J. A. (2003). Do tropical storm regimes influence the structure of tropical lowland rain forests? Biotropica, 35, 166-180.

Diamond, J. M. (1975). The island dilemma: Lessons of modern biogeographic studies for the design of natural reserves. Biological Conservation, 7, 129-146.

Drake, D. R. (1992). Seed dispersal of Metrosideros polymorpha (Myrtaceae): A pioneer tree of Hawaiian lava flows. American Journal of Botany, 79, 1224-1228.

AQ3 Dupon, J.-F. (1993). Atlas de la Polynésie française. Paris: Edition de l'Orstom.

Ellison, J. C. (2009). Wetlands of the Pacific island region. Wetlands Ecology and Management, $17,169-206$.

Elmqvist, T., Rainey, W. E., Pierson, E. D., \& Cox, P. A. (1994). Effects of tropical cyclones Ofa and Val on the structure of a Samoan lowland rain forest. Biotropica, 26, 384-391.

Etienne, S. (2012). Marine inundation hazards in French Polynesia: Geomorphic impacts of tropical Cyclone Oli in February 2010. Geological Society, London - Special Publications, 361, 21-39.

Felicísimo, Á., \& Muñoz, J. (2012). Le vent et la dispersion des plantes. Pour la Science, 416, $40-46$.

Florence, J. (1997). Flore de la Polynésie française (Vol. 1), Faune et Flore tropicale. Paris: IRD.

Florence, J. (2007). La Polynésie française: de l'histoire des plantes qui y poussent. Base de données Nadeaud de l'Herbier de Polynésie française (PAP) du Musée des Iles et de Tahiti. Papeete/Paris: Antenne IRD du MNHN.

Florence, J., Chevillotte, H., Ollier, C., \& Meyer, J.-Y. (2007). Base de données Nadeaud de l'Herbier de Polynésie française (PAP) du Musée des Iles et de Tahiti. Papeete: Antenne IRD du MNHN, Paris, Centre IRD de Tahiti, Délégation à la Recherche. Retrieved from http:// www.herbier-tahiti.pf

Florence, J., Waldren, S., \& Chepstow Lusty, A. (1995). The flora of the Pitcairn Islands: A review. Biological Journal of the Linnean Society, 56, 79-119.

Franklin, J., Drake, D. R., McConkey, K. R., Tonga, F., \& Smith, L. B. (2004). The effects of cyclone Waka on the structure of lowland tropical rain forest in Vava'u, Tonga. Journal of Tropical Ecology, 20, 409-420. 
Gilbert, F. S. (1980). The equilibrium theory of island biogeography: Fact or fiction? Journal of Biogeography, 7, 209-235.

Hamilton, T. H., Rubinoff, I., Barth, R. H., \& Bush, G. L. (1963). Species abundance: Natural regulation of insular variation. Science, 142, 1575-1577.

Hastings, P. A. (1990). Southern oscillation influences on tropical cyclone. International Journal of Climatology, 10, 291-298.

Herbert, D. A., Fownes, J. H., \& Vitousek, P. M. (1999). Hurricane damage to a Hawaiian forest: Nutrient supply rate affects resistance and resilience. Ecology, 80, 908-920.

Johnson, M. P., \& Raven, P. H. (1973). Species number and endemism: The Galapagos archipelago revisited. Science, 179, 893-895.

Kalmar, A., \& Currie, D. J. (2006). A global model of island biogeography. Global Ecology and Biogeography, 15, 72-81.

Keppel, G., Buckley, Y. M., \& Possingham, H. P. (2010). Drivers of lowland rain forest community assembly, species diversity and forest structure on islands in the tropical South Pacific. Journal of Ecology, 98, 87-95.

Kerr, A. M. (2000). Defoliation of an island (Guam, Mariana Archipelago, Western Pacific Ocean) following a saltspray-laden 'dry' typhoon. Journal of Tropical Ecology, 16, 895-901.

Kingston, N. (2001). The flora and vegetation of Pitcairn Island - its phytogeography and conservation ( $\mathrm{PhD}$ thesis). University of Dublin, Ireland.

Larrue, S., \& Chiron, T. (2010). Les îles de Polynésie française face à l'aléa cyclonique. VertigO, 10, Retrieved from http://vertigo.revues.org/10558

Losos, J. B., \& Schluter, D. (2000). Analysis of an evolutionary species-area relationship. Nature, 408, 847-850.

Lugo, A. E. (2008). Visible and invisible effects of hurricanes on ecosystems: An international review. Austral Ecology, 33, 368-398.

MacArthur, R. H., \& Wilson, E. O. (1967). The theory of island biogeography. Princeton University Press.

McMaster, R. T. (2005). Factors influencing vascular plant diversity on 22 islands off the coast of eastern North America. Journal of Biogeography, 32, 475-492.

Meyer, J.-Y. (2004). Threat of invasive alien plants to native flora and forest vegetation of Eastern Polynesia. Pacific Science, 58, 357-375.

Morand, S. (2000). Geographic distance and the role of island area and habitat diversity in the species area relationships of four Lesser Antillean faunal groups: A complementary note to Ricklefs and Lovette. Journal of Animal Ecology, 69, 1117-1119.

Morrison, L. W. (2002). Determinants of plant species richness on small Bahamian islands. Journal of Biogeography, 29, 931-941.

40 Mueller-Dombois, D. (2002). Forest vegetation across the tropical Pacific: A biogegraphically complex region with many analogous environments. Plant Ecology, 163, 155-176.

Mueller-Dombois, D., \& Fosberg, F. R. (1998). Vegetation of the Tropical Pacific Islands. New York, NY: Springer-Verlag.

Muñoz, J., Felicísimo, Á., Cabezas, F., Burgaz, A. R., \& Martínez, I. (2004). Wind as a long-distance dispersal vehicle in the southern hemisphere. Science, 304, 1144-1147.

Nunn, P. D. (1994). Oceanic islands. The natural environment series (Vol. I). Oxford: Blackwell.

Pascarella, J. B., Aide, T. M., \& Zimmerman, J. K. (2004). Short-term response of secondary forest to hurricane disturbance in Puerto Rico, USA. Forest Ecology and Management, 199, 379-393.

Paulay, G. (1994). Biodiversity on oceanic islands: Its origin and extinction. American Zoologist, $34,134-144$.

Preston, F. W. (1962a). The canonical distribution of commonness and rarity: Part I. Ecology, 43, $185-215$.

Preston, F. W. (1962b). The canonical distribution of commonness and rarity: Part II. Ecology, $43,410-432$.

Ricklefs, R. E., \& Lovette, I. J. (1999). The roles of island area per se and habitat diversity in the species area relationships of four lesser antillean faunal groups. Journal of Animal Ecology, 68, 1142-1160.

Rosenzweig, M. L. (1995). Species diversity in space and time. Cambridge, MA: Cambridge University Press. 
Rosindell, J., \& Phillimore, A. B. (2011). A unified model of island biogeography sheds light on the zone of radiation. Ecology Letters, 14, 552-560.

Royo, A. A., Scalley, T. H., Moya, S., \& Scatena, F. N. (2011). Non-arborescent vegetation trajectories following repeated hurricane disturbance: Ephemeral vs. enduring responses. Ecosphere, 2, art77.

Simberloff, D. (1995). Habitat fragmentation and population extinction of birds. Ibis, 137, $105-111$.

Stoddart, D. R. (1992). Biogeography of the Tropical Pacific. Pacific Science, 46, 276-293.

Triantis, K. A., Mylonas, M., Lika, K., \& Vardinoyannis, K. (2003). A model for the speciesarea-habitat relationship. Journal of Biogeography, 30, 19-27.

Turton, S. M., \& Siegenthaler, D. T. (2004). Immediate impacts of a severe tropical cyclone on the microclimate of a rain-forest canopy in north-east Australia. Journal of Tropical Ecology, 20, 583-586.

Van Balgooy, M. M. J. (1993). Pacific plant areas (Vol. 5). Leiden: Rijksherbarium/Hortus Botanicus, Leiden University.

Van Balgooy, M. M. J., Hovenkamp, P. H., \& van Welzen, P. C. (1996). Phytogeography of the Pacific - floristic and historical distribution patterns in plants. In A. Keast, \& S. E. Miller (Eds.), The origin and evolution of Pacific Island biotas, New Guinea to eastern Polynesia: Patterns and processes (pp. 191-213). Amsterdam: SPB Academic Publishing.

Vandermeer, J., de la Cerda, I., Boucher, D., Perfecto, I., \& Ruiz, J. (2000). Hurricane disturbance and tropical tree species diversity. Science, 290, 788-791.

Walker, L. R. (1991). Tree damage and recovery from hurricane Hugo in Luquillo experimental forest, Puerto Rico. Biotropica, 23, 379-385.

Whittaker, R. J., \& Fernández-Palacios, J. M. (2007). Island biogeography: Ecology, evolution, and conservation (2nd ed.). Oxford: Oxford University Press.

Whittaker, R. J., Willis, K. J., \& Field, R. (2001). Scale and species richness: Towards a general, hierarchical theory of species diversity. Journal of Biogeography, 28, 453-470.

Woodroffe, C. D., \& Stoddard, D. R. (1992). Substrata specificity and episodic catastrophe: Constraints on the insular plant geography of Suwarrow atoll, northern Cook Islands. Atoll Research Bulletin, 362, 1-19.

Wright, D. H. (1983). Species-energy theory: An extension of species-area theory. Oikos, 41, 496-506.

Wright, S. D., Yong, C. G., Dawson, J. W., Whittaker, D. J., \& Gardner, R. C. (2000). Riding the ice age El Niño? Pacific biogeography and evolution of Metrosideros subg. Metrosideros (Myrtaceae) inferred from nuclear ribosomal DNA. Proceedings of the National Academy of Sciences, 97, 4118-4123.

Zimmerman, J. K., Everham, E. M., Waide, R. B., Lodge, D. J., Taylor, C. M., \& Brokaw, N. V. L. (1994). Responses of tree species to hurricane winds in subtropical wet forest in Puerto Rico: Implications for tropical tree life histories. Journal of Ecology, 82, 911-922. 